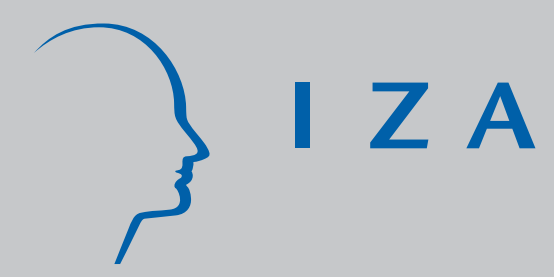

IZA DP No. 954

Six Ways to Leave Unemployment

Pedro Portugal

J ohn T. Addison

December 2003 


\title{
Six Ways to Leave Unemployment
}

\author{
Pedro Portugal \\ Banco de Portugal and Universidade Nova de Lisboa
}

John T. Addison

University of South Carolina

and IZA Bonn

Discussion Paper No. 954
December 2003

IZA

P.O. Box 7240

D-53072 Bonn

Germany

Tel.: +49-228-3894-0

Fax: +49-228-3894-210

Email: iza@iza.org

This Discussion Paper is issued within the framework of IZA's research area Evaluation of Labor Market Policies and Projects. Any opinions expressed here are those of the author(s) and not those of the institute. Research disseminated by IZA may include views on policy, but the institute itself takes no institutional policy positions.

The Institute for the Study of Labor (IZA) in Bonn is a local and virtual international research center and a place of communication between science, politics and business. IZA is an independent, nonprofit limited liability company (Gesellschaft mit beschränkter Haftung) supported by Deutsche Post World Net. The center is associated with the University of Bonn and offers a stimulating research environment through its research networks, research support, and visitors and doctoral programs. IZA engages in (i) original and internationally competitive research in all fields of labor economics, (ii) development of policy concepts, and (iii) dissemination of research results and concepts to the interested public. The current research program deals with (1) mobility and flexibility of labor, (2) internationalization of labor markets, (3) welfare state and labor market, (4) labor markets in transition countries, (5) the future of labor, (6) evaluation of labor market policies and projects and (7) general labor economics.

IZA Discussion Papers often represent preliminary work and are circulated to encourage discussion. Citation of such a paper should account for its provisional character. A revised version may be available on the IZA website (www.iza.org) or directly from the author. 
IZA Discussion Paper No. 954

December 2003

\section{ABSTRACT}

\section{Six Ways to Leave Unemployment}

This paper uses a unique Portuguese data set to examine the effect of unemployment benefit receipt and maximum duration of benefits on escape rates from unemployment. The focus is on the time profile of transitions out of unemployment. The novel aspect of the study resides in its identification of six destination states, namely, open-ended employment, fixed-term contracts, part-time work, government-provided jobs, self employment, and labor force withdrawal. Strong evidence of disincentive effects of the unemployment benefit system is reported. This result obtains both in general and for the various destination states, among which some marked behavioral differences are detected.

JEL Classification: J64, J65

Keywords: $\quad$ unemployment benefits, unemployment duration, competing risks

Corresponding author:

John T. Addison

Department of Economics

Moore School of Business

University of South Carolina

Columbia, SC 29208

USA

Tel.: +1 8037774608

Fax: +18037776876

Email: ecceaddi@moore.badm.sc.edu 


\section{Introduction}

This paper offers an examination of the impact of access to unemployment benefits in Portugal on unemployment duration. The effect of subsidization of the search process on jobless duration is of course familiar territory, and so the present treatment extends the conventional analysis in two main ways. First, it allows for time-varying effects of unemployment insurance benefits on jobless duration, as suggested by both the labor-leisure and job search models. Since this phenomenon has also been recognized in an admittedly sparser empirical literature (e.g. Meyer, 1990; Fallick, 1991; Narendranathan and Stewart, 1993a; Belzil, 1995), the second extension considered here allows for a variety of exit options available to the unemployed individual. To be sure, the extant literature has recognized that unemployment and inactivity are behaviorally distinct states (see Flinn and Heckman, 1983; Addison and Portugal, 2003), but has generally failed draw distinctions between different types of employment other than full-time and part-time jobs (Narendranathan and Stewart, 1993b; McCall, 1996). And to our knowledge there has been no attempt to investigate whether access to benefits serves in practice to mediate choices between these different routes to reemployment.

From a European perspective, it is germane to distinguish between open-ended or regular contracts of employment and fixed-term contracts. This is because the latter have tended to be the main means of circumventing ambitious employment protection rules. The classic example is provided by Spain where fixed-term contracts constitute 35 percent of all dependent employment and around 90 percent of all new contracts (Bover et al., 2000). Fixed-term contracts perform the function of a labor buffer stock and, to complicate matters, also serve as a screening mechanism for inducting workers into open-ended employment (Varejão and Portugal, 2001, 2002). Another 
distinction worth pursuing in a European context (especially relevant in Mediterranean or southern European nations) is the option of self employment again for reasons having to do with differential (i.e. more sweeping) employment protection legislation (see OECD, 1999). Finally, jobs provided through the public employment service are a more important exit option in Europe than in, say, the United States because of the greater emphasis placed on active labor market policies in the former region. And, although fixed term in nature, publicly-provided jobs should not be uncritically lumped together with the generality of fixed-term contracts. For all these reasons, a more realistic characterization of the European experience implies the identification of multiple destination states (see Bonnal et al., 1997). In addition to labor market withdrawal and part-time employment, therefore, we will also consider open-ended employment, fixed-term contracts, government-provided jobs, and self employment.

If individuals do indeed choose between a number of reemployment options (and inactivity), there are several sources of aggregation bias attaching to estimations based on an aggregate hazard function regression model. First, and most obviously, if individuals attach different utilities to the various alternatives to unemployment, regression effects may differ markedly across destinations. Thus, to take unemployment insurance as a case in point, access to benefits can materially influence the choice of destination state because the variable will enter as a negative (and possibly timevarying) cost in the individual utility function. More concretely, if the individual is drawing benefits in a regime that does not allow benefits to be paid in conjunction with part-time employment, it is unlikely that we will observe transitions into such employment prior to the point of benefit exhaustion. Second, the underlying cause-specific baseline hazard functions themselves may differ materially across destination states, thereby yielding differences in the timing of transitions out of 
unemployment for observationally-equivalent unemployed persons. For instance, if individuals place a higher value on permanent job offers than shorter-term employment opportunities they may be expected (initially at least) to search more intensively over the former type of vacancies. And, to take another example, transitions into part-time employment may only be observed after all hope of obtaining a full-time job is extinguished, at which point hazard rates would spike sharply. In short, use of an aggregate hazard function (and associated regression effects, including access to and duration of benefits) may be expected to compound distinct and possibly even contradictory influences. The disaggregated, competing risks treatment pursued here is designed to account for such differences with the overall objective of offering an improved understanding of unemployment transitions and the role of unemployment insurance in this regard.

Finally, the relevance of the Portuguese case is that it is broadly representative of continental Europe in terms its joblessness and institutional framework. At the same time, the stringency of its employment protection regime (Blanchard and Portugal, 2001) offers an interesting context in which to examine transitions into atypical work.

\section{Data}

Our data are taken from the nationally representative Portuguese quarterly employment surveys Inquérito ao Emprego for the period 1992(2)-1997(4), conducted by the Instituto Nacional de Estatistica (INE). The choice of period is dictated by changes in the methodology of the employment survey after the first quarter of 1992. The changes made included new sampling procedures and revisions to the definition of employment, unemployment, and inactivity.

Each quarter, the INE inquires of a random sample of individuals their current labor market 
status and past labor history. In this sense, just like the Current Population Survey, the Portuguese employment survey samples the population of members of a state at a given time and observes their elapsed durations. This sampling plan is referred to as stock sampling, and the elapsed (necessarily incomplete) durations are known as backward recurrence times. As is well known, the distribution of elapsed durations of a stock (of, say, the unemployed) gives a distorted image of the distribution of complete durations of a flow of entrants (in to the unemployment state). This is because the sampling plan over-samples long durations (so-called 'length biased sampling') and contains information only on spells currently in progress. As a result, mean unemployment duration is both over- and under-stated.

Such problems can be partially overcome, however, by a joint modeling of the elapsed duration distribution, the probability of being sampled, and the history of flows into a state. Yet this procedure may still impose too much structure on the data and require information on entrant flows that is typically unavailable to the researcher. A feasible and much simpler alternative procedureand that followed here - is available if the members of a state at a given time are observed over a fixed time interval. In these circumstances, we can obtain information on the remaining duration (or forward recurrence time) that, conditional on elapsed duration, is distributed as the entrant conditional density function (Lancaster, 1990).

The quarterly employment survey has a quasi-longitudinal capacity. One sixth of the sample rotate out of the sample each quarter, so that we can track transitions from unemployment for up to five quarters, and hence pursue the conditional approach. Transition rates are then obtained simply by identifying those unemployed individuals in the survey, and their elapsed duration in a given quarter, who move out of unemployment over the subsequent quarter. The destination states of 
previously unemployed workers can also be identified. For the present purposes, we shall distinguish between six such states: open-ended employment (i.e. permanent jobs), fixed-term contracts, part-time employment, jobs provided by the public employment agency, self employment, and economic inactivity (i.e. withdrawal from the labor force). We note parenthetically that publicly-provided jobs are at subsidized wages in the municipal sector and are fixed-term in nature.

Focusing for the moment on unemployment, each survey contains information on the length of the current unemployment spell in months and the unemployment benefit status of the worker as either a recipient or nonrecipient of benefits. 'Recipiency' may reflect either receipt of unemployment insurance proper or a lower order of unemployment benefits, termed unemployment assistance. We cannot with precision disentangle the two cetegories. Under Portuguese law, individuals have to have been employed for at least 18 months during the two years prior to the unemployment event to draw UI benefits proper. Individuals who do not fulfill these requirements can draw unemployment assistance if they have more than six months insured employment in the year preceding unemployment. In addition, workers who have exhausted UI benefits can claim unemployment assistance. In both cases, access to unemployment assistance hinges on per capita family income; only those whose per capita income is less than 80 percent of the minimum wage qualify for unemployment assistance.

For much of our analysis we will not distinguish between types of unemployment benefit recipient. Nevertheless, we will offer necessarily very tentative results for a measure of eligibility for the two types of unemployment benefit. The distinction is based solely on recipient status and tenure on the job that immediately preceded the unemployment event (our data do not contain information on per capita family income). In this exercise, persons recorded as collecting unemployment benefits 
who had at least 18 months of tenure on the last job are classified as eligible for UI benefits (ELIG). Those individuals drawing benefits with between 6 and 18 months of tenure on the last job are identified as recipients of unemployment assistance (ASSISTANCE). To repeat, this procedure is imprecise; in particular, those classified as recipients of unemployment assistance may in fact be receiving UI benefits if they had built up the necessary service requirement in (unobserved) jobs preceding that immediately prior to unemployment. That being said, the eligibility measure will assist us in going beyond the more aggregative results based on a simple benefits recipiency binary variable.

In addition to modeling the effects of recipiency (and, to a lesser extent, eligibility), we are also concerned to assess the impact of unemployment benefit duration on escape rates from unemployment and transitions to the various destination states. Under Portuguese law, duration of unemployment insurance benefits is exclusively a function of age. The maximum duration of benefits is 10 months for those aged less than 25 years and then rises in roughly 3 -month intervals for each incremental 5 years of age to 30 months at age $55 .^{1}$

As a practical matter, however, in calculating maximum duration we will assume, first, that all individuals recorded as collecting unemployment benefits are entitled to UI benefits and, second, that they do not go on to receive unemployment assistance. (Note, however, that even if such individuals do proceed to collect unemployment assistance, the reduced amount of benefits then payable would also produce a spike in the transition rate out of unemployment.) Maximum duration is of interest because it allows us to determine the individual's time to benefit exhaustion on the basis of his or her elapsed jobless duration. Again, maximum potential duration is derived from the unemployment insurance rules, so that any individual going on to collect unemployment assistance is 
nevertheless assigned a zero time to exhaustion at the exhaustion of regular benefits. This is, then, a conservative approach. ${ }^{2}$ Time-varying effects of unemployment benefits can be accommodated with information on the beneficiary's elapsed unemployment duration, either using the same intervals as employed for the baseline hazard or aggregating over certain of those intervals. In addition, nonlinearities can be introduced in to time to exhaustion of benefits. Both approaches will be deployed, our favored approach being the latter.

In sum, from the information in the survey we develop a number of variables to capture the effects of the unemployment benefit system. These are, first, a dummy variable denoting recipient status (compounding UI and unemployment assistance); second, a crude tenure-determined measure of eligibility for each type of benefit; and, third, remaining weeks of benefit entitlement (maximum duration of regular benefits less elapsed jobless duration). As noted, two methods of allowing for time-varying effects are also introduced.

The employment survey contains in addition to unemployment duration, destination status, and unemployment benefit status, information on the individual's age, marital status, level of schooling, tenure on the lost job, number of jobs held (and whether or not the individual is a new entrant to the labor market), broad occupational status, reason for job loss, and region of residence, inter al. Descriptive information on these and other variables is provided in the Appendix Table.

The main restrictions placed on the data were that the individual be unemployed at the time of the survey, aged between 16 and 64 years, and resident in mainland Portugal. Further, given wellknown gender differences in supply behavior, we also excluded females. Finally, in recognition of potential sample attrition, we ensured that individuals appearing in contiguous surveys with the same identifier were in fact the same individual. The resulting sample size is 9,451 individuals. 


\section{Methodology}

A useful concept in statistical analysis of duration is the notion of a hazard function. In the study of unemployment duration, the hazard function gives the instantaneous probability of exiting unemployment at $t$, given that the individual stayed unemployed until $t$

$$
h(t)=\lim _{\Delta t \rightarrow 0} \frac{P(t \leq T<t+\Delta t \mid T \geq t)}{\Delta t}=\frac{f(t)}{1-F(t)}=\frac{f(t)}{S(t)},
$$

where $f(t)$ is the probability density function, $F(t)$ is the distribution function, $S(t)$ is the survival function. A noteworthy relational function is the integrated hazard function

$$
\Lambda(t)=\int_{0}^{t} h(u) d u
$$

which relates to the survivor function simply by

$$
S(t)=e^{-\Lambda(t)}
$$

In this paper, we consider a flexible form for the hazard function, namely, the piecewiseconstant hazard function

$$
h(t)=\left\{\begin{array}{lll}
e^{\lambda_{1}} & \text { if } & 0 \leq t<c_{1} \\
e^{\lambda_{2}} & \text { if } & c_{1} \leq t<c_{2} \\
e^{\lambda_{3}} & \text { if } & c_{2} \leq t<c_{3} \\
\cdot & & \\
\cdot & & \\
e^{\lambda_{m-1}} & \text { if } & c_{K-1} \leq t
\end{array}\right.
$$

where the time axis is divided into $K$ intervals by points $c_{1}, c_{2} \ldots, c_{K-1}$. In specifying the baseline hazard function, we use eleven intervals. The first six intervals correspond to calendar months, the next two intervals are three months each, while the ninth and tenth intervals are of six months length. 
The final (open-ended) interval thus covers elapsed durations of twenty-five months or more. In other words, the knot points are 1, 2, 3, 4, 5, 6, 9, 12, 18, and 24 .

We shall also distinguish between six exit modes out of unemployment: full-time fixed-term contracts, full-time open-ended contracts, part-time employment, self-employment, public employment, and inactivity. Hence, we define the cause-specific hazard functions to destination $j$ as

$$
h_{j}(t)=\lim _{\Delta t \rightarrow 0} \frac{P(t \leq T<t+\Delta t \mid T \geq t, J=j)}{\Delta t}, \quad \mathrm{j}=1,2, \ldots 6
$$

yielding the aggregate hazard function

$$
h(t)=\sum_{j=1}^{6} h_{j}(t)
$$

and the survivor function

$$
S(t)=\prod_{j=1}^{6} S^{j}(t)
$$

where $S^{j}(t)=e^{-\Lambda^{j}(t)}$, and $\Lambda^{j}(t)=\int_{0}^{t} h_{j}(u) d u$.

The model has a conventional competing risks interpretation. In this framework, a latent duration $\left(T_{j}\right)$ unemployment attaches to each exit mode. We only observe the minimum of each latent variable. If risks are assumed to be independent, with continuous duration, this model simplifies to six separate single-cause hazard models.

A popular way to accommodate the presence of observed individual heterogeneity is to specify a proportional hazards model

$$
h_{j}(t ; x)=h_{0 j}(t) e^{x^{\prime} \beta_{j}}
$$


where $h_{0 j}(t)$ denotes the baseline specific hazard function, that is, the hazard function corresponding to null values for the covariates $x$. In this case, the covariates affect the hazard function proportionally (i.e. $\left.\frac{d h_{j}(x)}{d x_{k}}=\beta_{k} h_{j}(x)\right)$. An implication of this assumption is that impact of the covariates does not change (in relative terms) with the progression of the spell of unemployment.

Our information on elapsed duration of unemployment is grouped into monthly intervals (while transitions can only observed over a fixed interval of three months). Let $M=m$ denote the occurrence of an exit in a given month $\left[c_{t-1}, c_{t}\right)$, where $m$ is the realization of a discrete random unemployment duration variable $M \in(1, \ldots, K)$. The probability that an event occurs in the $m^{\text {th }}$ interval (that is, an exit occurs over the course of the three-month window), and that such an exit is to destination $r$, will be given by

$$
f_{m}^{r}=\frac{S_{m-3}^{r}-S_{m}^{r}}{S_{m-3}^{r}} S_{m-3}=h_{m}^{r} S_{m-3},
$$

where we neglect $t$ and $x$ for the sake of parsimony.

The functions $f_{m}^{r}$ and $\left(1-S_{m}^{r}\right)$ provide a convenient characterization of the probability density and the cumulative functions associated with the marginal distribution for each latent duration, $T_{j}$, in terms of the specific hazard function $h_{m}^{r}$. A censored observation (namely, a spell of unemployment that is still in progress after the three-month window) occurs with probability $S_{m}=\prod_{j=1}^{6} S_{m}^{j}$, which is simply the product of the specific survivor functions.

Apart from the discrete nature of the unemployment duration data, we need to pay attention to the type of sampling plan being used in order to avoid the length bias sampling problems induced 
by stock sampling (Flinn, 1986). Recall that in our sample the stock of unemployed individuals is observed over a fixed interval of three months. In other words, at the time of the first survey the elapsed duration of unemployment is recorded. Three months later, the labor market status of the same individual is observed, providing us with information on whether he or she had left unemployment and, if so, the destination state. With this sampling plan, we need to condition on elapsed duration at the time of the first interview in order to recover the entrant density function.

The likelihood contribution for a single individual is given by

$$
L(\theta \mid t, j, x)=\left\{\prod_{m=1}^{K-1} \prod_{j=1}^{6}\left[\frac{S_{m-3}^{j}-S_{m}^{j}}{S_{m-3}^{j}}\right]^{\delta_{m j}}\right\}\left\{\prod_{m=2}^{K}\left[\frac{S_{m}}{S_{m-3}}\right]\right\}^{1-\delta_{m}},
$$

where $\theta$ is a vector of parameters that include regression coefficients and baseline hazard parameters, and $\delta_{m j}$ is an indicator that assumes the value of one if the individual exits to destination $j$ during the $m^{\text {th }}$ interval, and zero otherwise. The indicator $\delta_{m}=\sum_{j=1}^{6} \delta_{m j}$ identifies completed durations, so that, $1-\delta_{m}$ equals 1 for a censored observation. Notice that, after conditioning on having survived until $m$ - $t$, the $S_{m-3}$ term cancels out for completed durations. The contribution to the likelihood function from a censored observation is simply the product, conditional on surviving up to $m-3$, of the six specific survival terms $\left(\prod_{j=1}^{6} S_{m}^{j}\right)$

We have yet to incorporate the presence of unobserved individual heterogeneity. Familiarly, this is achieved by assuming a multiplicative error term associated with each specific hazard function 


$$
h_{j}(t ; x)=h_{0 j}(t) e^{x^{\prime} \beta_{j}} v_{j}
$$

We further assume that the errors $v_{\mathrm{j}}$ are gamma distributed with mean 1 and variance $\sigma_{j}^{2}$ and are uncorrelated.

We then proceed by redefining the specific survivor function using the well-known result for gamma mixtures $\bar{S}_{m}^{j}=\left(1+\sigma_{j}^{2} \Lambda_{m}^{j}\right)^{-1 / \sigma_{j}^{2}}$ (see Lancaster, 1990, p. 66). After this transformation, the likelihood function is derived as for equation (10) above

$$
L\left(\theta, \sigma_{j}^{2} \mid t, j, x\right)=\left\{\prod_{m=1}^{K-1} \prod_{j=1}^{6}\left[\frac{\left(1+\sigma_{j}^{2} \Lambda_{m-3}^{j}\right)^{-1 / \sigma_{j}^{2}}-\left(1+\sigma_{j}^{2} \Lambda_{m}^{j}\right)^{-1 / \sigma_{j}^{2}}}{\left(1+\sigma_{j}^{2} \Lambda_{m-3}^{j}\right)^{-1 / \sigma_{j}^{2}}}\right]^{\delta_{m j}}\right\}\left\{\prod_{m=2}^{K} \prod_{j=1}^{6}\left[\frac{\left(1+\sigma_{j}^{2} \Lambda_{m}^{j}\right)^{-1 / \sigma_{j}^{2}}}{\left(1+\sigma_{j}^{2} \Lambda_{m-3}^{j}\right)^{-1 / \sigma_{j}^{2}}}\right]\right\}^{1-\delta_{m}} .
$$

\section{Findings}

Over our sample period, Portuguese unemployment rose by almost two-thirds - from 4.1.to 6.7 percent - and the mean (elapsed) duration of unemployment increased every year from 12.2 months in 1992 to 16.5 months in 1997. Not surprisingly, the distribution of unemployment has changed fairly profoundly; in particular, the share of long-term unemployment (12 months or more) rose by almost 75 percent, such that by the end of the sample period a little over two in five workers had been out of work for more than a year. But the proportion of workers covered by the unemployment benefit system has not changed since 1993. Also, the maximum duration of benefits and the replacement rate (65 percent) have remained unchanged. Accordingly, it is the sharp increase in the number of unemployed individuals, and their jobless duration, that explain the near three-fold increase in nominal outlays on unemployment benefits between 1992 and 1997.

Against this backdrop, we first consider the probability of escaping unemployment at the most general level (i.e. without distinguishing between destination states). An initial indication of the 
effects of unemployment benefits on escape rates is provided by the empirical hazard functions in Figure 1. Despite the narrowing in the difference between the escape rates of recipients and nonrecipients through time, there is prima facie evidence of both marked and persistent disincentive effects of access to benefits.

\section{(Figure 1 near here)}

Results for the basic duration model are given in Table 1. As was noted earlier, the baseline hazard function is specified as an eleven-segment piecewise-constant function. The coefficient estimates in the table show the effects of the regressors in proportionally shifting the baseline hazard up or down. The coefficient estimate of the variable of principal interest indicates that receipt of unemployment benefits (the UB dummy) decreases the chance of exiting unemployment by 42 percent. The assumption that this disincentive effect is constant through time will of course subsequently be relaxed.

(Table 1 near here)

The effects of the other covariates can be very briefly described. First, note that we use seven age dummies - the omitted category is individuals aged less than 25 years - to coincide with the age-determined nature of duration entitlement. Absent this specification, it could be argued that the unemployment benefit effect is picking up the effects of aging on jobless duration. As can be seen, this is not the case because the decline in escape rates with age is near monotonic. Second, the effects of the TENURE, DISABLED, SCHOOLING, and MARRIED covariates are thoroughly conventional, with the first two arguments serving to reduce escape rates and the last two being associated with higher escape rates. Third, greater labor market experience/knowledge, indexed by the JOBS variable (and also negatively by FIRST JOB), seems to translate in to reduced joblessness. 
Note in particular that new entrants are 21 percent less likely to exit from unemployment than other job seekers. On the other hand, whether or not a worker lost his job by reason of a mass layoff or through the termination of a fixed-term contract (respectively, LAYOFF and END FIXED) seems to play no part in influencing escape rates. Finally, and as expected, the current unemployment rate is a powerful determinant of escape rates, while the pattern of regional dummies picks up the persistence of unemployment rate differences across broad areas of the country (the high hazard rates of the Center region being notable in this regard).

(Table 2 near here)

We next consider summary results from alternative characterizations of the effect of unemployment benefits on escape rates. The entry in the first column of Table 2 simply carries over the unemployment benefit (UB) coefficient estimate from Table 1. Specification (2) uses the alternative benefits measure TIMEEX, namely, time to exhaustion of benefits. It will be recalled that this measure pertains to the exhaustion of UI benefits and does not allow for any subsequent receipt of unemployment assistance. ${ }^{3}$ It is apparent that escape rates decline substantially, the further is the insured unemployed worker from benefit expiration; specifically, the hazard rate declines by 4.1 percent for each remaining month of entitlement.

Specification (3) substitutes two imputed benefit measures for one, namely, ELIG and ASSISTANCE. ELIG proxies eligibility for UI benefits and ASSISTANCE the entitlement to lower-tier benefits in the form of social assistance. As we have seen, each is defined on the basis of the unemployed individual's length of service in the job immediately preceding the unemployment event, given recipiency. Of the two measures, imputed receipt of regular benefits has the stronger effect. The relevant comparison is with the UB coefficient estimate in specification (1). Since the 
effect of actual receipt of benefits compounds the two effects, it follows that replacement rates drive the result that imputed receipt of UI is stronger than actual benefit receipt.

The balance of the material in Table 2 allows for time-varying effects in UB receipt (specifications (4) and (5)), as well as nonlinearities in the TIMEEX measure (specification (6)). As far as actual benefit receipt is concerned, specification (4) identifies time-varying effects by using the same intervals as the baseline hazard, whereas specification (5) offers a more parsimonious characterization by aggregating over those intervals. In the former case, it can be seen that the negative effects of benefits on escape rates last for up to two years. In the latter case, the use of a smaller number of intervals confirms the persistence of the benefits effect but perhaps makes more transparent the result that this influence is not monotonic over the spell of joblessness.

For its part, the introduction of nonlinearities in the effects of TIMEEX provides evidence of rather dramatic disincentive effects, the longer the interval to benefit exhaustion. For example, with two or more years of remaining entitlement, the recipient is 53 percent less likely to escape from unemployment than his uninsured counterpart. At one year the difference is still 48 percent, falling very modestly to 47 percent at six months, and then more steeply to 35 percent at 3 months and to 14 percent at one month.

(Table 3 near here)

We next consider the issue of destination state. Sample means of jobless duration and time to exhaustion of benefits (both in months), as well as unemployment benefit status, are given in Table 3. Comparing the still unemployed (in the next quarter) with individuals entering the six destination states, it can be seen that their elapsed unemployment duration is much longer. The proportion of unemployment benefit recipients is also much greater among the remaining unemployed, with the 
obvious exception of those securing public employment. Individuals on government-sponsored manpower programs typically draw unemployment benefits prior to enrollment.

From the base of Table 3, it can be seen that the most common form of transition is to fixed-term contracts rather than open-ended employment. ${ }^{4}$ In terms of elapsed duration, however, open-ended employment has the shortest associated joblessness. As implied earlier, part-time employment is associated with the most protracted unemployment, although we caution that the number of transitions in this case is rather small. Finally, vis-à-vis the remaining destination states, self-employed persons and those entering in to fixed-term contracts use up most of their benefits.

(Table 4 near here)

The disaggregated version of the piecewise-constant hazards regression (first presented in Table 1) is given in Table $4 .^{5}$ The estimates correct for unobserved individual heterogeneity. It is immediately apparent that the regression coefficients vary widely from destination state to destination state. ${ }^{6}$ Abstracting from differences in the effects of unemployment benefits - which will be examined in detail below - there are a number of other interesting results. Thus, for example, the probability of finding employment in open-ended employment and fixed-term contracts is declining in age. But these effects of age are confined to full-time employment. (Not unexpectedly, similar results but of opposing sign are reported for married individuals.). These findings caution against uncritical aggregation by destination state. Another interesting result is that disability is associated with a sharply reduced likelihood of entering into open-ended employment. Although the same is true of labor market inexperience, those who have ended their first job are also more likely to become inactive which is patently not the case for disabled individuals. Further, the probability of escaping in to permanent jobs is negatively associated with the unemployment rate. For other 
destination states no such statistically significant relation is evident, with the one exception of inactivity. Interestingly, there are indications that labor market withdrawal rises in recovery and falls in recessions, pointing to the absence of conventional discouragement effects.

Perhaps the most interesting differences revealed by Table 4, however, pertain to open-ended employment versus fixed-term contracts. There are material differences in most of the coefficient estimates other than benefit receipt. The main result is that workers exiting in to fixed-term contracts are typically high-turnover groups. That is, such workers are more likely to be labor market entrants, to have been employed under fixed-term contracts in the past, to have held a larger number of jobs, and to have lower tenure. On the other hand, there is also the seemingly awkward result that workers with greater schooling are also more likely to transition in to fixed-term contracts and less likely to find open-ended employment. The likely reconciliation is that there are two rather different processes underlying full-time employment that operate in tandem. The dominant story remains the high turnover one: fixed-term contracts are used as a buffer labor stock by employers, with high-turnover groups locating and taking such employment. But firms also seem to use fixed-term contracts as a screen and to deploy the screen more frequently in the case of educated individuals. Research using other data sets indicates that it is palatable for more educated workers to take employment under fixed-term contracts because such individuals have better prospects of subsequently exiting in to open-ended employment (see Varejão and Portugal, 2001, 2002).

(Table 5 near here)

The rest of our analysis is devoted exclusively to the effects of access to and duration of unemployment benefits on the probability of entering a particular destination state. Panel (a) of Table 5 carries over the UB findings from Table 4 and supplements them with summary results from 
a specification that substitutes TIMEEX for the binary unemployment benefits measure, UB. The general opening observation is that, again with the obvious exception of publicly-provided employment, there are strong disincentive effects of unemployment benefits across all destination states. Beginning with the UB variable, perhaps the most striking result is the absolute magnitude of the disincentive effect in the case of part-time employment - and, to a somewhat lesser extent, for self employment. Unemployment benefit recipients are respectively seven times and three times less likely than recipients to enter these states. Neither result is surprising: insured workers have reservation wages that typically exceed the part-time wage, while for self employment the outcome presumably reflects optimal timing considerations (see below). There is no indication that unemployment benefits facilitate entry in to stable jobs - compare the very similar point estimates for UB in open-ended employment and fixed-term contracts - but we have already commented on the possibility that for some individuals fixed-term contracts are a means of subsequently accessing open-ended employment.

The time to benefit exhaustion measure, TIMEEX, provides some additional information on the role of unemployment benefits. Disincentive effects for other than those entering public employment are indicated throughout and in each case parallel those obtained for the UB binary measure. Although the smallest disincentive effects are observed for fixed-term contracts, there is now even less to differentiate the two forms of full-time employment.

(Figure 2 near here)

Panel (b) of Table 5 provides results for nonlinearities in the effects of TIMEEX. To facilitate interpretation, the relationships are also graphed in Figure 2, which again expresses the percentage changes in transition rates of insured recipients over the entitlement period, nonrecipients being the 
benchmark. The figure omits part timers and public employment because of the small number of transitions in to these destination states and the large standard errors of the coefficient estimates.) The pattern is roughly consistent across destination states. That is, there is the suggestion that escape rates rise - albeit at different rates - as the benefit period shrinks. Open-ended employment is something of an exception in having relatively high escape rates for the two most remote intervals (Figure 3 near here)

Baseline hazard functions, again corresponding to the specification in panel (b) of the table, are given in Figure 3. The functions apply to an individual with sample average characteristics in respect of the continuous variables SCHOOLING, TENURE, JOBS, and UNEMPLOYMENT RATE, but who is assigned a zero values - that is, the omitted categories - for all the dichotomous variables including of course recipient time to exhaustion. Beginning with the main destination states of open-ended employment and fixed-term contracts, it is apparent that the former baseline hazard is characterized by declining escape rates as spell length progresses. The fall is precipitous over the first four months of unemployment although it is much reduced thereafter. For fixed-term contracts, the decline in escape rates is much less evident. Indeed, generally high hazard rates characterize this destination state. Taken in conjunction, however, the two baseline hazards perhaps contain the suggestion that some unemployed job seekers initially looking for open-ended employment switch to sampling fixed-term contracts after a period of unsuccessful search.

Evidence of possible switching behavior is more clearly revealed by the $\mathrm{W}$-shaped pattern of the baseline hazard for transitions in to part-time work. The argument here might be that at least two waves of unemployed individuals after unproductive search for full-time jobs ultimately settle on part-time employment, while those wanting such jobs ab initio locate them fairly quickly. For its 
part, the pattern of the baseline hazard for transitions in to government-provided jobs provides only weak evidence that the public authorities target the long-term unemployed.

As far as labor force withdrawal and self employment are concerned there is evidence of positive duration dependence, with rising escape rates over time. This is most obviously the case for inactivity where the rising profile of escape rates is now more indicative of discouragement. Finally, escape rates into self employment display a pattern reminiscent of the part-time destination state. That is, there is every indication that those who value self-employment find such work readily with others tending to drift in to self employment thereafter.

\section{Conclusions}

This paper has used a unique data set to investigate the effects of unemployment benefits on jobless duration. Apart from its representative nature and useful human capital/demographic content, the data set contains information on unemployment benefit recipiency, has a quasi-longitudinal capacity, and permits identification of a larger number of destination states than has been used in the duration literature. Unlike administrative data, however, it does not contain information on benefit duration (which has to be imputed) or on the amount of benefits received. That being said, the former deficiency is mitigated by the exclusively age-related nature of benefit duration in Portugal, while the latter omission is not really a problem given the general uniformity of replacement rates.

The major innovation of the paper has been the use of a competing risks model to characterize transitions out of unemployment, thereby accommodating behaviorally distinct choices on the part of job seekers. Our results confirmed that one cannot assume common regression coefficients across destination states. The use of an aggregate approach was shown to compound 
distinct and even contradictory effects of the covariates.

In investigating the effects of the various unemployment benefit measures, large disincentive effects were observed across all destination states. The exception, and one that was anticipated, was the public employment option. Some more specific findings were the huge disincentive effect of unemployment benefits on transitions into part-time employment, and use of part-time employment in part as a last resort. There was also evidence of muted discouragement effects in respect of transitions in to self employment and inactivity. Another interesting result was the similarity in the effect of unemployment benefits as between open-ended employment and fixed-term contracts. Consequently, access to unemployment benefits does not seem to help workers obtain stable jobs. However, there are two very different mechanisms at work here. On the one hand, high-turnover workers flow into and out of fixed-term contracts as employers take advantage of the unemployment insurance system. On the other hand, fixed-term contracts also seem to be used as a screening device that eventually leads to permanent jobs.

One result that may surprise readers is the near uniform disincentive effect of unemployment benefits across the main ways of exiting unemployment (open-ended employment, temporary employment, self-employment, and inactivity). Apparently the moral hazard aspect of subsidization dominates the intended insurance function of the unemployment benefit system irrespective of the exit options available.

An obvious policy implication of our analysis is that individuals should be allowed to draw benefits for some period after they transition in to part-time employment. (Reassuringly, Portuguese law has recently been revised to allow this very option.) The more general policy implication is of course that the maximum duration of benefits should be reduced and the age criterion removed 
where it might usefully be replaced by one based on previous job attachment. A final implication would be that the Portuguese unemployment insurance system would benefit from introduction of experience rating on the U.S. pattern so as to discourage the use by employers of excessive buffer stocks of fixed-term contract workers. 


\section{Endnotes}

1. For those insured recipients who have exhausted their regular benefits, the maximum duration of unemployment assistance is one-half that due under UI proper. Thus, for a 24 -year old, the maximum duration of unemployment assistance would be another five months of income support. For unemployment assistance recipients proper, the maximum duration of these (reduced) benefits is exactly the same as applies for UI benefits, and is age determined. Note that the replacement rate for unemployment insurance ranges between 100 and 300 percent of the minimum wage, whereas for unemployment assistance it is only 70-100 percent of the minimum wage.

2. Results from relaxing the assumption that insured individuals do not subsequently draw unemployment assistance for the relevant age-related period will be noted in passing below. Full results are available from the authors on request.

3. When we reran the regression assuming that all those who received UI benefits proper went on to collect the maximum (age-determined) duration of unemployment assistance, the benefits coefficient estimate was somewhat reduced in absolute magnitude.

4. Although the number of fixed-term transitions is high, it is the case that their frequency is markedly lower than in neighboring Spain. This difference reflects the relatively stricter rules governing fixed-term contracts in Portugal (see Bover et al., 2000).

5. To save on computational cost, age is redefined to be a continuous variable rather than a categorical variable as formerly.

6. A log-likelihood ratio test confirmed that there were statistically significant differences in the destination-specific regression coefficients at the .001 level: $\chi^{2}(100)=684.9$. Equally, a test based on the null that the baseline hazard functions differ only by a multiplicative constant confirmed that they were indeed distinct, the null being rejected at the .05 level: $\chi^{2}(50)=68.8$. 


\section{References}

Addison, John T., and Pedro Portugal. 2003. "Unemployment Duration: A Competing Risks Model with Defective Risks.” Journal of Human Resources 38: 156-191.

Belzil, Christian. 1995. “Unemployment Insurance and Unemployment Over Time: An Analysis with Event History Data." Review of Economics and Statistics 77: 113-126.

Blanchard, Olivier, and Pedro Portugal. 2001. "What Hides Behind an Unemployment Rate: Comparing Portuguese and U.S. Labor Markets,” American Economic Review 91, 187-207.

Bonnal, Liliane, Denis Fougère, and Anne Sérandon. 1997. "Evaluating the Impact of French Employment Policies on Individual Labor Market Histories." Review of Economic Studies 64: 683-713.

Bover, Olympia, Pilar García-Perea, and Pedro Portugal. 2000. "Labour Market Outliers: Lessons from Portugal and Spain.” Economic Policy 31: 381-428.

Fahrmeir, Ludwig, and Gerhard Tutz. 1994. Multivariate Statistical Modelling Based on Generalized Linear Models. Berlin and New York: Springer.

Fallick, Bruce Chelimsky. 1991. "Unemployment Insurance and the Reemployment Rate of Displaced Workers." Review of Economics and Statistics 73: 228-235.

489

Journal Flinn, Christopher J. 1986. "The Econometric Analysis is of CPS-Type Unemployment Data.” Journal of Human Resources 21: 456-489.

Flinn, Christopher J., and James J. Heckman. 1983. "Are Unemployment and Out of the Labor Force Behaviorally Distinct Labor Market States?" Journal of Labor Economics 1: 28-42.

Lancaster, Tony. 1990. The Econometric Analysis of Transition Data. Cambridge: Cambridge University Press. 
McCall, Brian P. 1996. "Unemployment Insurance Rules, Joblessness, and Part-Time Work." Econometrica 64: 647-682.

Meyer, Bruce D. 1990. "Unemployment Insurance and Unemployment Spells." Econometrica 58: 757-782.

Narendranathan, Wiji, and Mark B. Stewart. 1993a. "How Does the Unemployment Effect Vary as Unemployment Spell Lengthens?" Journal of Applied Econometrics 8: 361-381.

Narendranathan, Wiji, and Mark B. Stewart. 1993b. "Modelling the Probability of Leaving Unemployment: Competing Risks Models with Flexible Base-Line Hazards." Applied Statistics 42: 63-83.

OECD. 1999. "Employment Protection and Labor Market Performance." Employment Outlook (June): 49-132.

Varejão, José and Pedro Portugal. 2001. "Why Do Firms Use Fixed-Term Contracts?" Unpublished paper, University of Porto.

Varejão, José and Pedro Portugal. 2002. "Matching Workers to Jobs on the Fast Lane: The Operation of Fixed-Term Contracts" Unpublished paper, University of Porto. 
Figure 1: Empirical Hazard Functions by Unemployment Benefit Recipiency Status

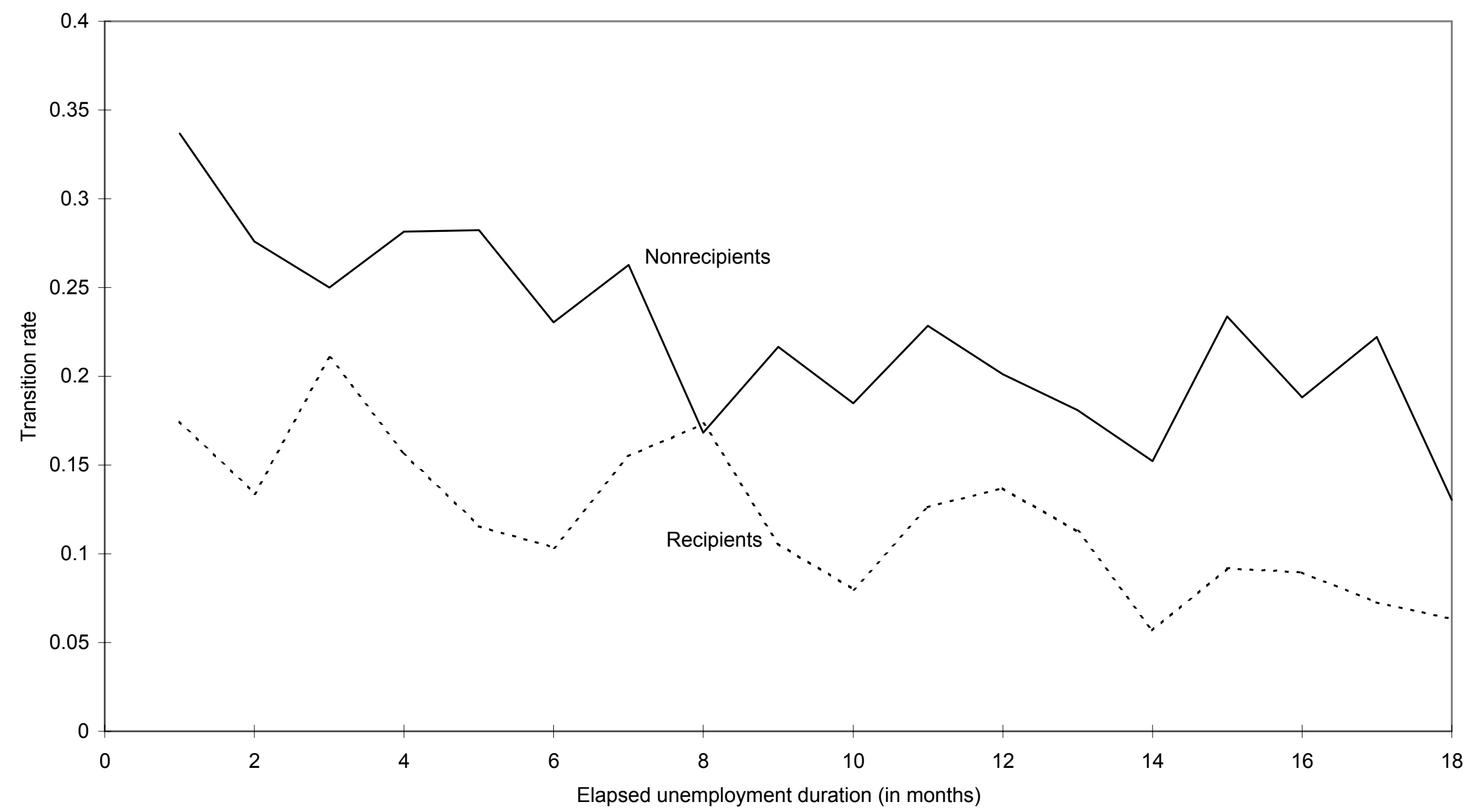


Figure 2: The Relative Effects of Time to Exhaustion on Escape Rates by Grouped Intervals

Open-ended employment

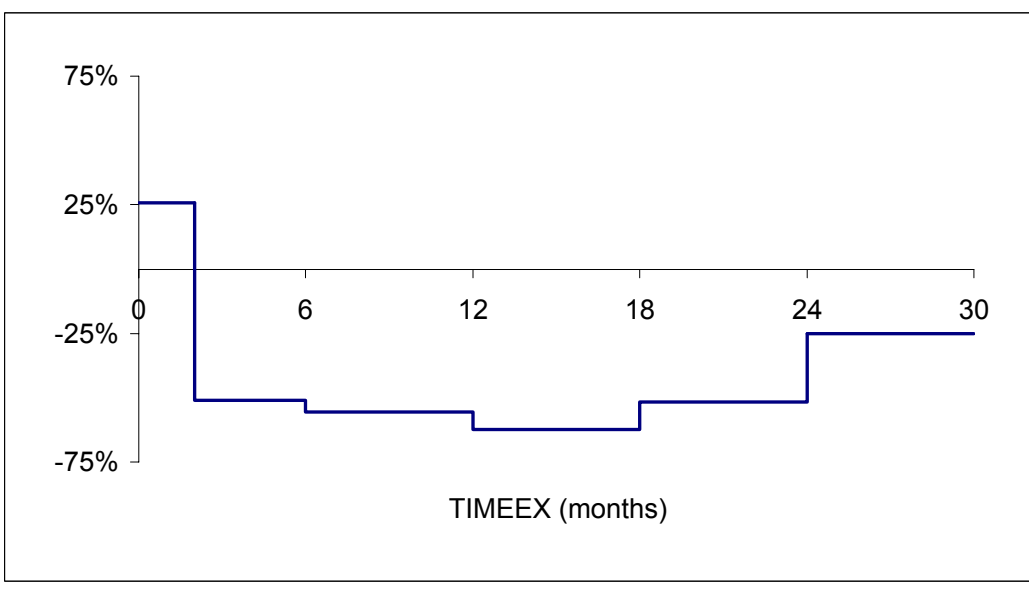

\section{Self employment}

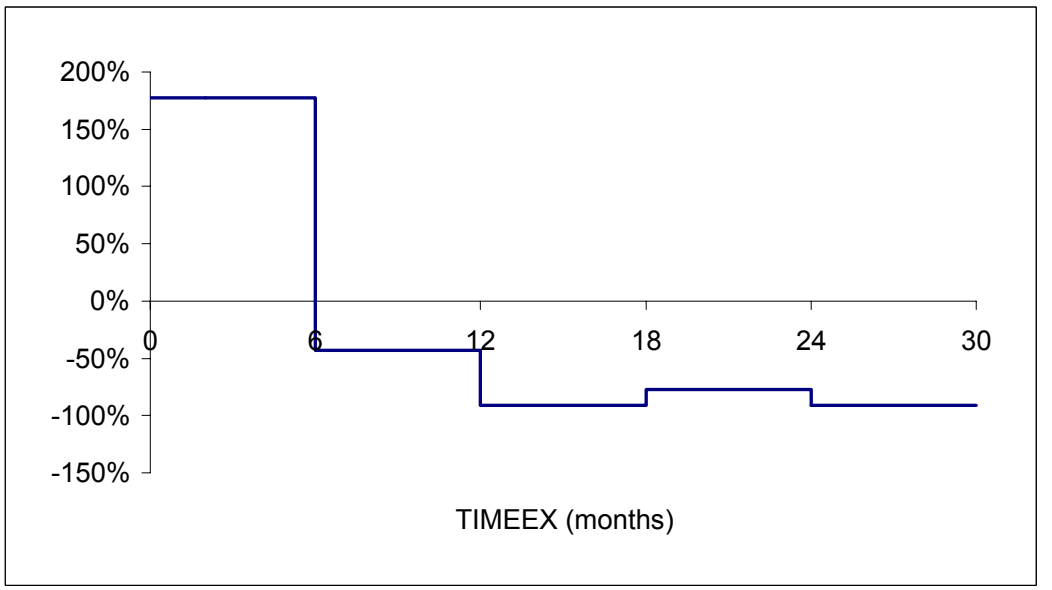

Fixed-term contract

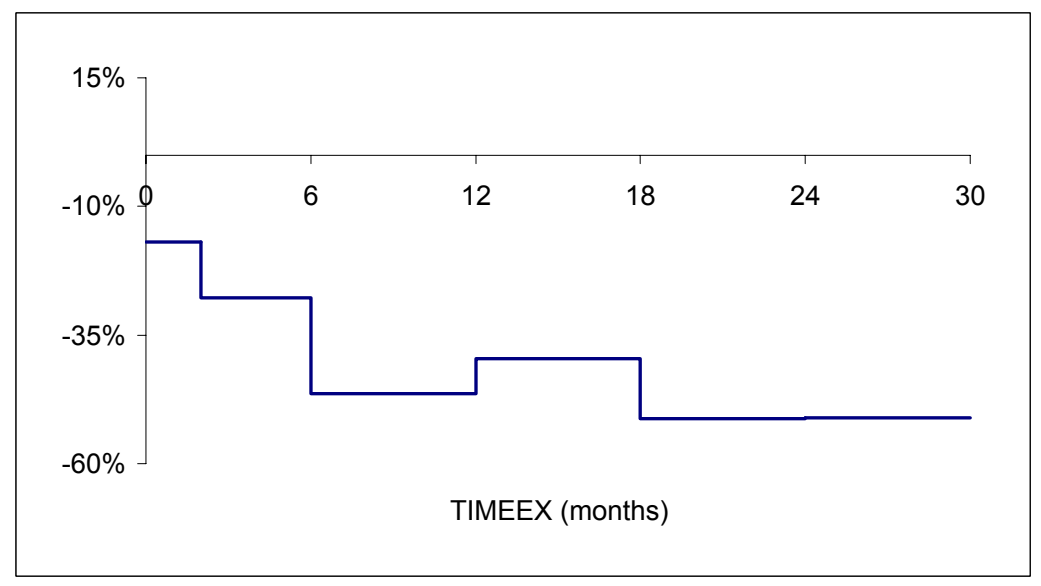

Inactivity

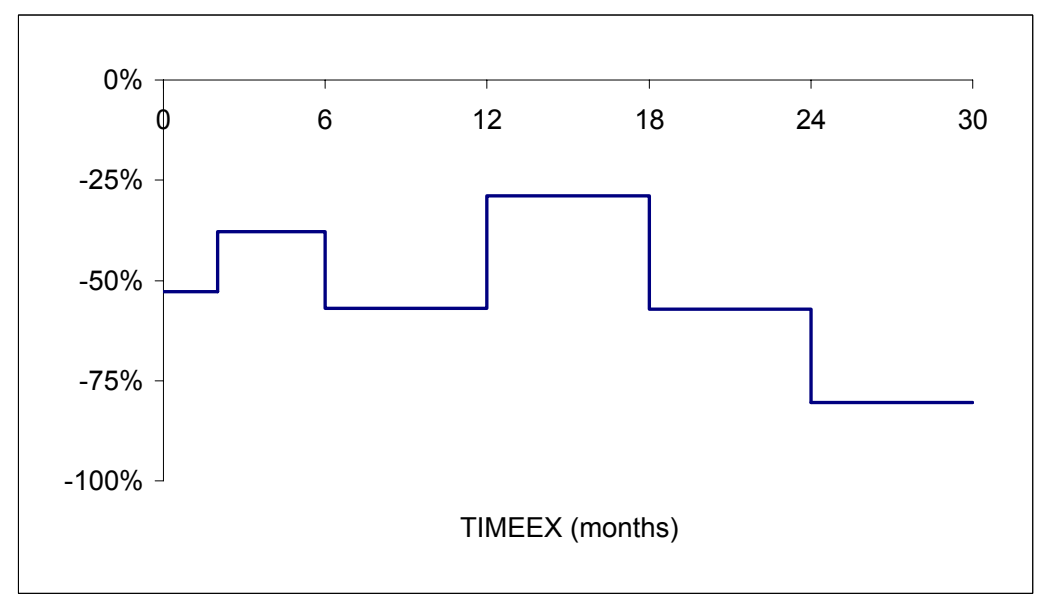


Figure 3: Baseline Hazard Functions by Destination State

\section{Open-ended employment}

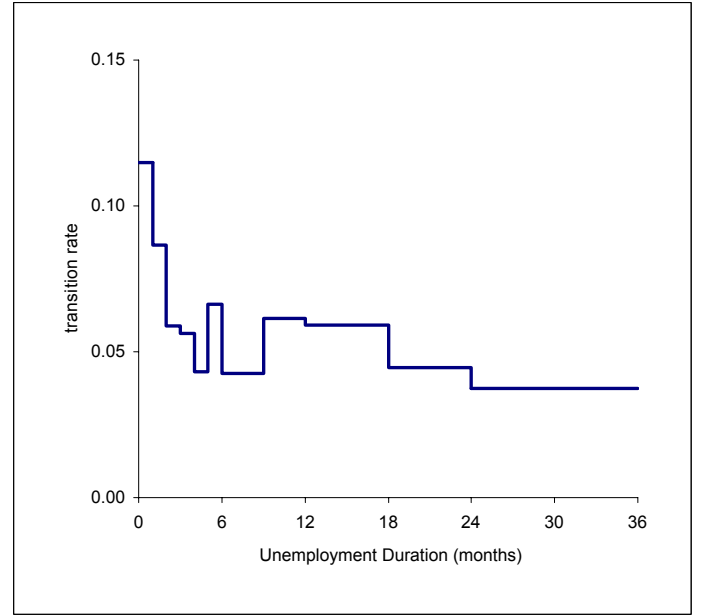

\section{Part-time employment}

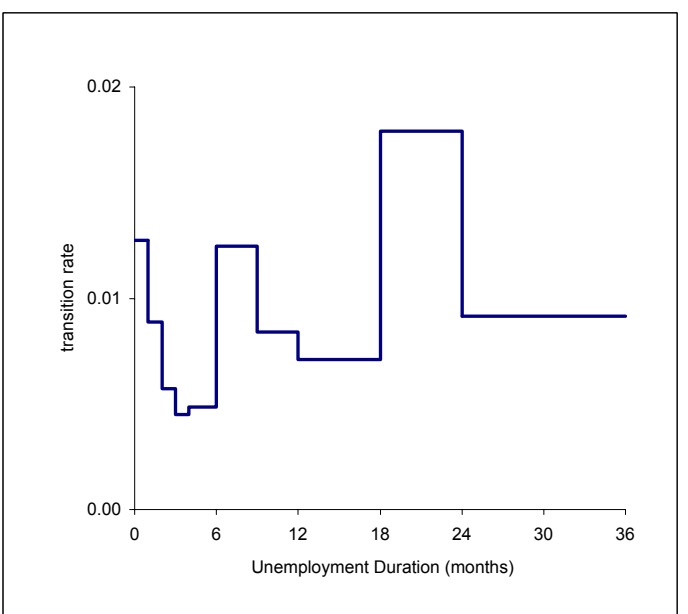

Self employment

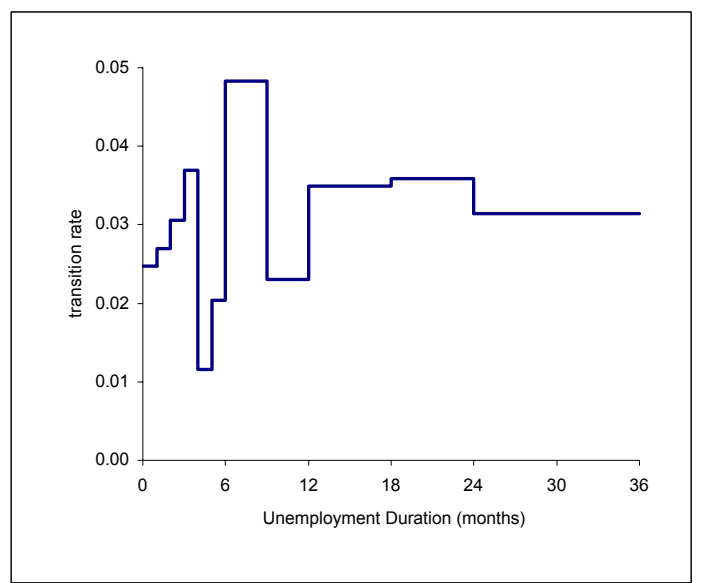

Fixed-term contract

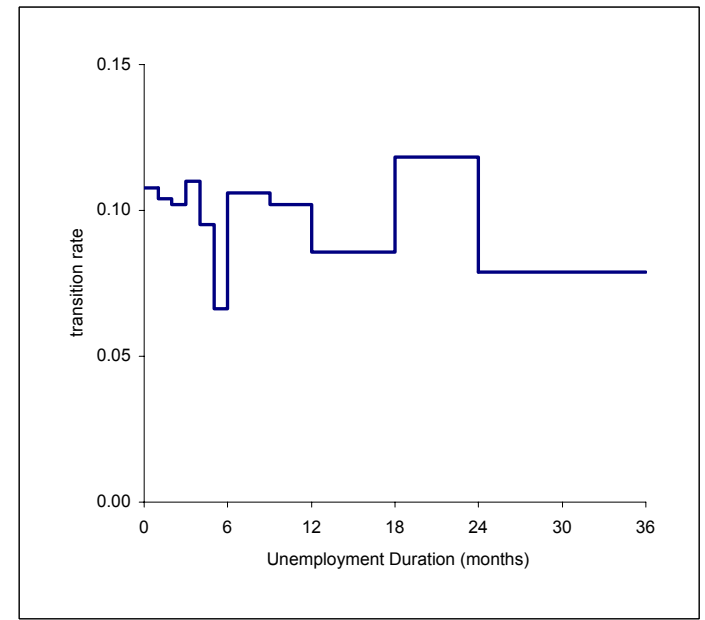

\section{Public employment}

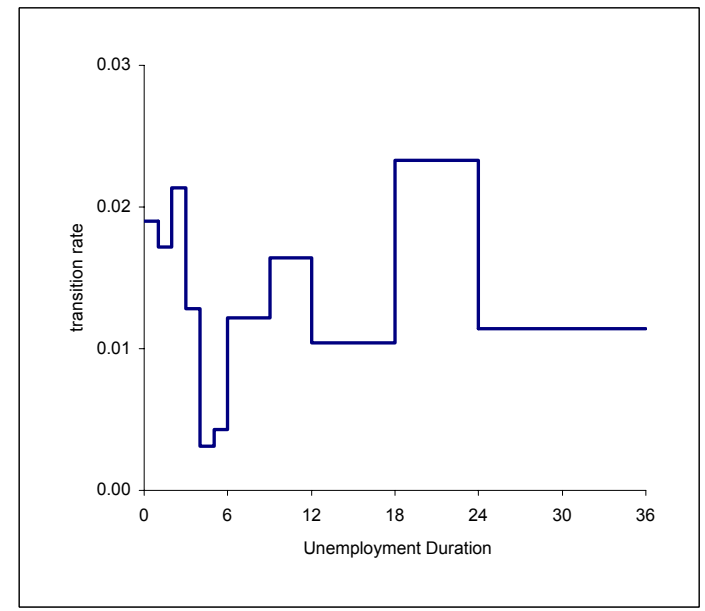

Inactivity

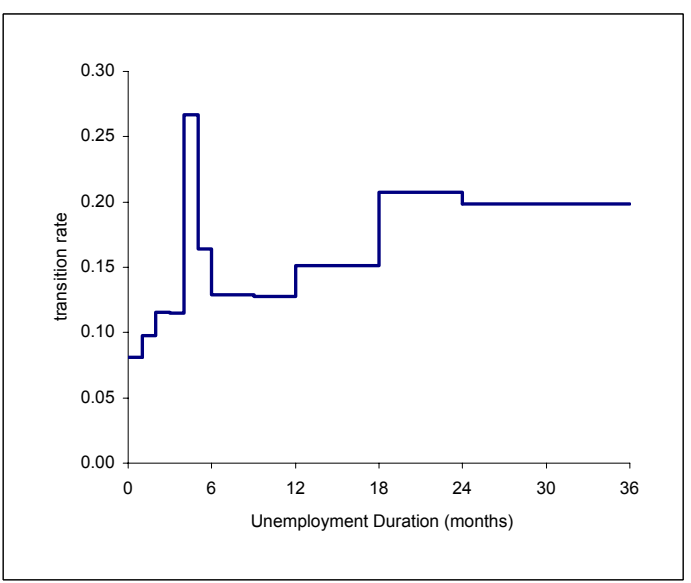


Table 1: Estimated Piecewise-Constant Hazards Regression, Aggregate Model $(n=9,451)$

\begin{tabular}{|c|c|}
\hline Variable & Coefficient Estimate \\
\hline UB & $\begin{array}{l}-0.550 \\
(0.064)\end{array}$ \\
\hline \multicolumn{2}{|l|}{ AGE GROUP } \\
\hline $25-29$ & $\begin{array}{l}-0.030 \\
(0.075)\end{array}$ \\
\hline $30-34$ & $\begin{array}{l}-0.190 \\
(0.092)\end{array}$ \\
\hline $35-39$ & $\begin{array}{l}-0.298 \\
(0.112)\end{array}$ \\
\hline $40-44$ & $\begin{array}{l}-0.143 \\
(0.110)\end{array}$ \\
\hline $45-49$ & $\begin{array}{l}-0.296 \\
(0.125)\end{array}$ \\
\hline $50-54$ & $\begin{array}{l}-0.377 \\
(0.134)\end{array}$ \\
\hline $55+$ & $\begin{array}{c}-0.738 \\
(0.137)\end{array}$ \\
\hline SCHOOLING & $\begin{array}{c}0.015 \\
(0.008)\end{array}$ \\
\hline TENURE & $\begin{array}{l}-0.010 \\
(0.004)\end{array}$ \\
\hline JOBS & $\begin{array}{c}0.021 \\
(0.007)\end{array}$ \\
\hline WHITE COLLAR & $\begin{array}{l}-0.109 \\
(0.074)\end{array}$ \\
\hline MARRIED & $\begin{array}{c}0.244 \\
(0.071)\end{array}$ \\
\hline DISABILITY & $\begin{array}{c}-0.665 \\
(0.239)\end{array}$ \\
\hline FIRSTJOB & $\begin{array}{l}-0.237 \\
(0.085)\end{array}$ \\
\hline LAYOFF & $\begin{array}{l}-0.087 \\
(0.084)\end{array}$ \\
\hline END FIXED & $\begin{array}{c}0.079 \\
(0.060)\end{array}$ \\
\hline UNEMPLOYMENT RATE & $\begin{array}{l}-0.056 \\
(0.026)\end{array}$ \\
\hline REGIONAL DUMMIES & \\
\hline NORTH & $\begin{array}{l}-0.236 \\
(0.080)\end{array}$ \\
\hline CENTER & $\begin{array}{c}0.059 \\
(0.098)\end{array}$ \\
\hline LISBOA & $\begin{array}{l}-0.229 \\
(0.078)\end{array}$ \\
\hline ALGARVE & $\begin{array}{l}-0.256 \\
(0.107)\end{array}$ \\
\hline Log-likelihood & -4361.755 \\
\hline
\end{tabular}

Asymptotic standard errors in parenthesis 
Table 2: Summary Results of the Effect of Unemployment Benefits on Transitions Out of Unemployment $(n=9,451)$

\begin{tabular}{lccc}
\hline Variable & \multicolumn{2}{c}{ Sp } \\
\cline { 2 - 4 } UB & $(1)$ & $(2)$ & $(3)$ \\
TIMEEX & -0.550 & & \\
ELIG & $(0.064)$ & & \\
& & -0.042 & \\
ASSISTANCE & $(0.005)$ & -0.625 \\
& & $(0.083)$ \\
Recipient Elapsed Duratior & & -0.483 \\
& & $(0.128)$
\end{tabular}

Recipient Elapsed Duratior

$\begin{array}{cc}1 \text { month } & -0.704 \\ 2 \text { months } & (0.165) \\ & -0.738 \\ 3 \text { months } & (0.190) \\ & -0.180 \\ 4 \text { months } & (0.174) \\ & -0.698 \\ 5 \text { months } & (0.230) \\ & -0.917 \\ 6 \text { months } & (0.252) \\ 7-9 \text { months } & -0.820 \\ & (0.268) \\ 10-12 \text { months } & -0.323 \\ & (0.159) \\ 13-18 \text { months } & -0.478 \\ & (0.168) \\ 19-24 \text { months } & -0.758 \\ & (0.193) \\ & -0.603 \\ & (0.244) \\ & -0.135 \\ & (0.197)\end{array}$

Recipient Elapsed Duration

1-6 months

7-12 months

$(0.117)$

$-0.756$

(0.193)

$-0.333$

(0.239)

Recipient Time to Exhaustion

$\begin{array}{lr}1-2 \text { months } & -0.147 \\ 3-5 \text { months } & (0.229) \\ & -0.434 \\ 6-11 \text { months } & (0.175) \\ & -0.631 \\ 12-17 \text { months } & (0.099) \\ & -0.647 \\ 18-23 \text { months } & (0.125) \\ & -0.691 \\ \text { months or more } & (0.150) \\ & -0.752 \\ & (0.228)\end{array}$

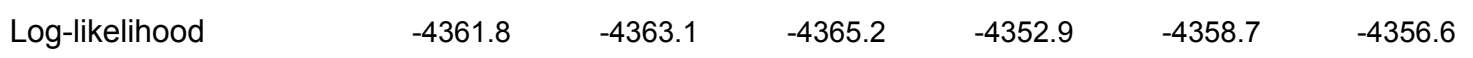


Table 3: Mean Values of Elapsed Duration and Unemployment Benefit Status by Destination State

\begin{tabular}{|c|c|c|c|c|c|c|c|}
\hline \multirow[b]{2}{*}{ Variable } & \multicolumn{5}{|c|}{ Destination state $^{a}$} & \multirow[b]{2}{*}{ Inactivity } & \multirow[b]{2}{*}{ Unemployed } \\
\hline & Open-ended employment & Fixed-term contract & Part time & Public employment & Self employment & & \\
\hline DURATION & 8.991 & 9.297 & 13.865 & 10.606 & 11.685 & 13.905 & 14.670 \\
\hline UB & 0.223 & 0.206 & 0.077 & 0.451 & 0.260 & 0.210 & 0.362 \\
\hline TIMEEX & 10.569 & 9.353 & 12.200 & 12.125 & 9.212 & 9.781 & 10.573 \\
\hline Number of event & 457 & 743 & 104 & 71 & 119 & 305 & 7652 \\
\hline
\end{tabular}

Note: andividuals that exit unemployment in to any of the six categories in the subsequent quarter 
Table 4: Estimated Piecewise-Constant Hazards Regression with Gamma Heterogeneity by Destination State $(n=9,451)$

\begin{tabular}{|c|c|c|c|c|c|c|}
\hline \multirow[b]{2}{*}{ Variable } & \multicolumn{6}{|c|}{ Transition to: } \\
\hline & Open-ended employment & Fixed-term contract & Part time & Self employment & Public employment & Inactivity \\
\hline UB & $\begin{array}{c}-0.660 \\
(0.140)\end{array}$ & $\begin{array}{l}-0.626 \\
(0.123)\end{array}$ & $\begin{array}{l}-1.989 \\
(0.505)\end{array}$ & $\begin{array}{l}-1.063 \\
(0.349)\end{array}$ & $\begin{array}{c}0.547 \\
(0.369)\end{array}$ & $\begin{array}{c}-0.612 \\
(0.226)\end{array}$ \\
\hline AGE & $\begin{array}{c}-0.026 \\
(0.008)\end{array}$ & $\begin{array}{l}-0.033 \\
(0.007)\end{array}$ & $\begin{array}{l}-0.003 \\
(0.017)\end{array}$ & $\begin{array}{c}0.016 \\
(0.019)\end{array}$ & $\begin{array}{l}-0.020 \\
(0.020)\end{array}$ & $\begin{array}{c}0.008 \\
(0.010)\end{array}$ \\
\hline SCHOOLING & $\begin{array}{l}-0.027 \\
(0.018)\end{array}$ & $\begin{array}{c}0.038 \\
(0.016)\end{array}$ & $\begin{array}{c}0.044 \\
(0.039)\end{array}$ & $\begin{array}{c}0.118 \\
(0.046)\end{array}$ & $\begin{array}{c}-0.002 \\
(0.064)\end{array}$ & $\begin{array}{c}0.007 \\
(0.029)\end{array}$ \\
\hline TENURE & $\begin{array}{l}-0.018 \\
(0.010)\end{array}$ & $\begin{array}{l}-0.040 \\
(0.011)\end{array}$ & $\begin{array}{l}-0.012 \\
(0.021)\end{array}$ & $\begin{array}{l}-0.001 \\
(0.019)\end{array}$ & $\begin{array}{l}-0.049 \\
(0.033)\end{array}$ & $\begin{array}{c}0.014 \\
(0.012)\end{array}$ \\
\hline JOBS & $\begin{array}{c}0.005 \\
(0.018)\end{array}$ & $\begin{array}{c}0.043 \\
(0.012)\end{array}$ & $\begin{array}{l}-0.013 \\
(0.065)\end{array}$ & $\begin{array}{c}0.053 \\
(0.037)\end{array}$ & $\begin{array}{c}0.018 \\
(0.035)\end{array}$ & $\begin{array}{l}-0.010 \\
(0.037)\end{array}$ \\
\hline WHITE COLLAR & $\begin{array}{l}-0.242 \\
(0.177)\end{array}$ & $\begin{array}{l}-0.381 \\
(0.149)\end{array}$ & $\begin{array}{l}-0.190 \\
(0.344)\end{array}$ & $\begin{array}{c}0.239 \\
(0.395)\end{array}$ & $\begin{array}{l}-0.389 \\
(0.464)\end{array}$ & $\begin{array}{c}0.177 \\
(0.241)\end{array}$ \\
\hline MARRIED & $\begin{array}{c}0.349 \\
(0.156)\end{array}$ & $\begin{array}{c}0.398 \\
(0.137)\end{array}$ & $\begin{array}{c}0.356 \\
(0.326)\end{array}$ & $\begin{array}{c}0.484 \\
(0.396)\end{array}$ & $\begin{array}{c}0.384 \\
(0.403)\end{array}$ & $\begin{array}{l}-0.428 \\
(0.275)\end{array}$ \\
\hline DISABILITY & $\begin{array}{l}-1.047 \\
(0.540)\end{array}$ & $\begin{array}{l}-0.862 \\
(0.465)\end{array}$ & $\begin{array}{c}0.322 \\
(0.736)\end{array}$ & $\begin{array}{l}-0.793 \\
(1.299)\end{array}$ & $\begin{array}{c}0.804 \\
(0.711)\end{array}$ & $\begin{array}{l}-1.449 \\
(0.761)\end{array}$ \\
\hline FIRSTJOB & $\begin{array}{l}-0.807 \\
(0.212)\end{array}$ & $\begin{array}{l}-0.400 \\
(0.165)\end{array}$ & $\begin{array}{c}-0.291 \\
(0.436)\end{array}$ & $\begin{array}{l}-1.306 \\
(0.683)\end{array}$ & $\begin{array}{l}-0.826 \\
(0.640)\end{array}$ & $\begin{array}{c}0.811 \\
(0.268)\end{array}$ \\
\hline LAYOFF & $\begin{array}{c}0.140 \\
(0.171)\end{array}$ & $\begin{array}{c}0.052 \\
(0.169)\end{array}$ & $\begin{array}{c}0.058 \\
(0.441)\end{array}$ & $\begin{array}{l}-0.111 \\
(0.468)\end{array}$ & $\begin{array}{l}-0.230 \\
(0.509)\end{array}$ & $\begin{array}{l}-0.719 \\
(0.303)\end{array}$ \\
\hline END FIXED & $\begin{array}{l}-0.099 \\
(0.128)\end{array}$ & $\begin{array}{c}0.398 \\
(0.113)\end{array}$ & $\begin{array}{c}0.366 \\
(0.286)\end{array}$ & $\begin{array}{l}-0.104 \\
(0.334)\end{array}$ & $\begin{array}{l}-0.011 \\
(0.353)\end{array}$ & $\begin{array}{l}-0.310 \\
(0.217)\end{array}$ \\
\hline UNEMPLOYMENT RATE & $\begin{array}{l}-0.150 \\
(0.056)\end{array}$ & $\begin{array}{l}-0.004 \\
(0.050)\end{array}$ & $\begin{array}{c}0.004 \\
(0.124)\end{array}$ & $\begin{array}{l}-0.028 \\
(0.158)\end{array}$ & $\begin{array}{l}-0.047 \\
(0.163)\end{array}$ & $\begin{array}{l}-0.200 \\
(0.088)\end{array}$ \\
\hline NORTH & $\begin{array}{l}-0.058 \\
(0.175)\end{array}$ & $\begin{array}{l}-0.175 \\
(0.156)\end{array}$ & $\begin{array}{c}0.459 \\
(0.480)\end{array}$ & $\begin{array}{l}-0.206 \\
(0.546)\end{array}$ & $\begin{array}{l}-1.280 \\
(0.478)\end{array}$ & $\begin{array}{l}-0.824 \\
(0.275)\end{array}$ \\
\hline CENTER & $\begin{array}{c}0.129 \\
(0.219)\end{array}$ & $\begin{array}{c}0.120 \\
(0.195)\end{array}$ & $\begin{array}{c}1.392 \\
(0.605)\end{array}$ & $\begin{array}{l}-0.335 \\
(0.744)\end{array}$ & $\begin{array}{l}-1.240 \\
(0.773)\end{array}$ & $\begin{array}{c}0.015 \\
(0.323)\end{array}$ \\
\hline LISBOA & $\begin{array}{l}-0.264 \\
(0.183)\end{array}$ & $\begin{array}{c}-0.068 \\
(0.151)\end{array}$ & $\begin{array}{c}0.603 \\
(0.500)\end{array}$ & $\begin{array}{c}0.175 \\
(0.498)\end{array}$ & $\begin{array}{l}-1.235 \\
(0.538)\end{array}$ & $\begin{array}{l}-0.567 \\
(0.260)\end{array}$ \\
\hline ALGARVE & $\begin{array}{l}-0.294 \\
(0.244)\end{array}$ & $\begin{array}{l}-0.339 \\
(0.211)\end{array}$ & $\begin{array}{c}0.278 \\
(0.642)\end{array}$ & $\begin{array}{l}0.905 \\
(0.617)\end{array}$ & $\begin{array}{l}-0.013 \\
(0.507)\end{array}$ & $\begin{array}{l}-0.861 \\
(0.381)\end{array}$ \\
\hline sigma & $\begin{array}{c}0.495 \\
(0.115)\end{array}$ & $\begin{array}{c}0.347 \\
(0.298)\end{array}$ & $\begin{array}{c}0.474 \\
(1.528)\end{array}$ & $\begin{array}{c}1.473 \\
(0.515)\end{array}$ & $\begin{array}{c}0.145 \\
(2.889)\end{array}$ & $\begin{array}{c}0.794 \\
(0.212)\end{array}$ \\
\hline Log-likelihood & \multicolumn{6}{|c|}{-6689.14} \\
\hline
\end{tabular}

Asymptotic standard errors in parenthesis 
Table 5: Summary Results of the Effect of Unemployment Benefits on Transitions Out of Unemployment by Destination State $(n=9,451)$

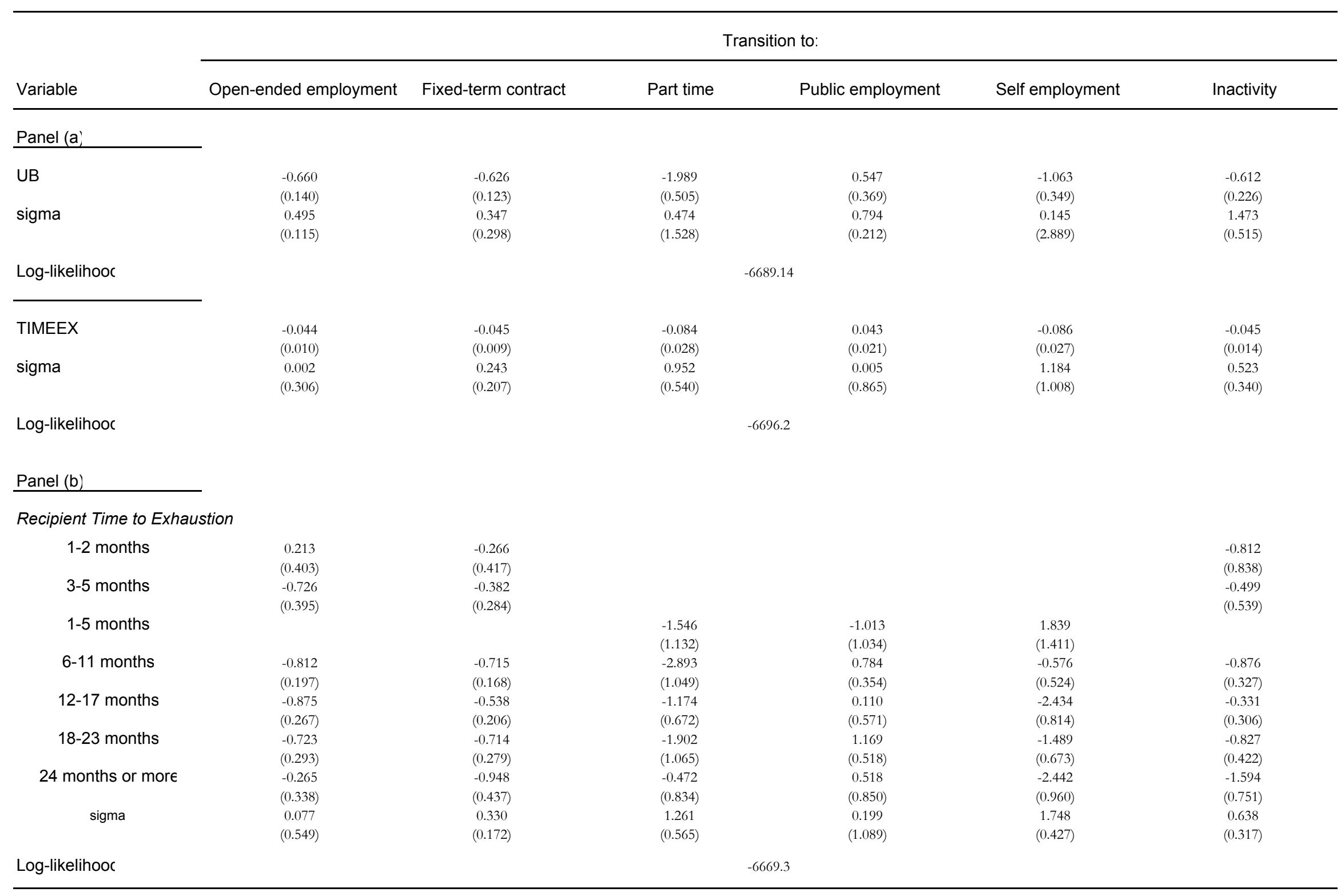

Asymptotic standard errors in parenthesis

Note: The full array of covariates are given in Table 2 
Appendix Table: Definition of Variables and Descriptive Statistics by Unemployment Benefit Recipiency

\begin{tabular}{|c|c|c|c|c|}
\hline \multirow[b]{2}{*}{ Variable } & \multicolumn{2}{|c|}{ Recipient } & \multicolumn{2}{|c|}{ Nonrecipient } \\
\hline & mean & s.d. & mean & s.d. \\
\hline UNOUT & 0.125 & & 0.223 & \\
\hline $\begin{array}{l}\text { transition out of unemployment }=1,0 \text { otherwise } \\
\text { DURATION }\end{array}$ & 11.828 & 11.240 & 14.888 & 18.764 \\
\hline $\begin{array}{l}\text { AGE } \\
\text { age in years }\end{array}$ & 41.816 & 12.704 & 30.826 & 12.381 \\
\hline $\begin{array}{l}\text { SCHOOLING } \\
\text { years of schooling completed }\end{array}$ & 5.771 & 3.430 & 7.117 & 3.782 \\
\hline $\begin{array}{l}\text { TENURE } \\
\text { years of tenure on previous job }\end{array}$ & 9.785 & 10.408 & 3.900 & 7.710 \\
\hline $\begin{array}{l}\text { JOBS } \\
\text { number of previous jobs }\end{array}$ & 3.483 & 3.925 & 2.508 & 3.444 \\
\hline $\begin{array}{l}\text { WHITE COLLAR } \\
=1 \text { if white-collar employee, } 0 \text { otherwise }\end{array}$ & 0.232 & & 0.168 & \\
\hline $\begin{array}{l}\text { MARRIED } \\
=1 \text { if married, } 0 \text { otherwise }\end{array}$ & 0.741 & & 0.341 & \\
\hline $\begin{array}{l}\text { DISABILITY } \\
=1 \text { if disabled, } 0 \text { otherwise }\end{array}$ & 0.015 & & 0.021 & \\
\hline $\begin{array}{l}\text { FIRSTJOB } \\
=1 \text { if looking for first iob, } 0 \text { otherwise }\end{array}$ & & & 0.231 & \\
\hline $\begin{array}{l}\text { LAYOFF } \\
=1 \text { if job lost by reason of mass lavoff, } 0 \text { otherwise }\end{array}$ & 0.305 & & 0.090 & \\
\hline $\begin{array}{l}\text { END FIXED } \\
=1 \text { if job lost through termination of a fixed-term contract, } 0 \text { otherwise }\end{array}$ & 0.258 & & 0.258 & \\
\hline $\begin{array}{l}\text { UNEMPLOYMENT RATE } \\
\text { quarterly unemployment rate }\end{array}$ & 6.640 & 0.839 & 6.540 & 0.940 \\
\hline $\begin{array}{l}\text { NORTH } \\
=1 \text { for the North region, } 0 \text { otherwise }\end{array}$ & 0.400 & & 0.351 & \\
\hline CENTER & 0.076 & & 0.087 & \\
\hline $\begin{array}{l}=1 \text { for the Center region, } 0 \text { otherwise } \\
\text { LISBOA }\end{array}$ & 0.347 & & 0.358 & \\
\hline $\begin{array}{l}=1 \text { for the Lisboa and Vale do Tejo region, } 0 \text { otherwise } \\
\text { ALGARVE } \\
=1 \text { for the Algarve region, } 0 \text { otherwise }\end{array}$ & 0.070 & & 0.090 & \\
\hline$n$ & & & & \\
\hline
\end{tabular}




\section{IZA Discussion Papers}

\begin{tabular}{|c|c|c|c|c|}
\hline No. & Author(s) & Title & Area & Date \\
\hline 940 & $\begin{array}{l}\text { A. Constant } \\
\text { Y. Shachmurove } \\
\text { K. F. Zimmermann }\end{array}$ & $\begin{array}{l}\text { What Makes an Entrepreneur and Does It Pay? } \\
\text { Native Men, Turks, and Other Migrants in } \\
\text { Germany }\end{array}$ & 1 & $11 / 03$ \\
\hline 941 & $\begin{array}{l}\text { R. V. Burkhauser } \\
\text { J. S. Butler } \\
\text { G. Gumus }\end{array}$ & $\begin{array}{l}\text { Option Value and Dynamic Programming Model } \\
\text { Estimates of Social Security Disability Insurance } \\
\text { Application Timing }\end{array}$ & 6 & $11 / 03$ \\
\hline 942 & $\begin{array}{l}\text { R. V. Burkhauser } \\
\text { J. S. Butler } \\
\text { G. Gumus }\end{array}$ & $\begin{array}{l}\text { Dynamic Modeling of the SSDI Application } \\
\text { Timing Decision: The Importance of Policy } \\
\text { Variables }\end{array}$ & 6 & $11 / 03$ \\
\hline 943 & $\begin{array}{l}\text { J. T. Addison } \\
\text { P. Teixeira }\end{array}$ & $\begin{array}{l}\text { What Have We Learned About the Employment } \\
\text { Effects of Severance Pay? Further Iterations of } \\
\text { Lazear et al. }\end{array}$ & 3 & $11 / 03$ \\
\hline 944 & $\begin{array}{l}\text { H. Görg } \\
\text { D. Greenaway }\end{array}$ & $\begin{array}{l}\text { Much Ado About Nothing? Do Domestic Firms } \\
\text { Really Benefit from Foreign Direct Investment? }\end{array}$ & 2 & $11 / 03$ \\
\hline 945 & $\begin{array}{l}\text { R. Schöb } \\
\text { D. E. Wildasin }\end{array}$ & $\begin{array}{l}\text { Economic Integration and Labor Market } \\
\text { Institutions: Worker Mobility, Earnings Risk, and } \\
\text { Contract Structure }\end{array}$ & 2 & $12 / 03$ \\
\hline 946 & M. Leonardi & $\begin{array}{l}\text { Earnings Instability of Job Stayers and Job } \\
\text { Changers }\end{array}$ & 1 & $12 / 03$ \\
\hline 947 & U. Sunde & $\begin{array}{l}\text { Potential, Prizes and Performance: Testing } \\
\text { Tournament Theory with Professional Tennis } \\
\text { Data }\end{array}$ & 7 & $12 / 03$ \\
\hline 948 & $\begin{array}{l}\text { A. Kugler } \\
\text { G. Pica }\end{array}$ & $\begin{array}{l}\text { Effects of Employment Protection and Product } \\
\text { Market Regulations on the Italian Labor Market }\end{array}$ & 6 & $12 / 03$ \\
\hline 949 & C. J. Flinn & $\begin{array}{l}\text { Minimum Wage Effects on Labor Market } \\
\text { Outcomes under Search with Bargaining }\end{array}$ & 6 & $12 / 03$ \\
\hline 950 & $\begin{array}{l}\text { P. Garibaldi } \\
\text { E. Wasmer }\end{array}$ & $\begin{array}{l}\text { Equilibrium Employment in a Model of Imperfect } \\
\text { Labor Markets }\end{array}$ & 1 & $12 / 03$ \\
\hline 951 & $\begin{array}{l}\text { P. Garibaldi } \\
\text { E. Wasmer }\end{array}$ & $\begin{array}{l}\text { Raising Female Employment: Reflexions and } \\
\text { Policy Tools }\end{array}$ & 5 & $12 / 03$ \\
\hline 952 & $\begin{array}{l}\text { O. Raaum } \\
\text { K. G. Salvanes } \\
\text { E. Ø. Sørensen }\end{array}$ & The Neighbourhood Is Not What It Used to Be & 3 & $12 / 03$ \\
\hline 953 & $\begin{array}{l}\text { O. Raaum } \\
\text { K. G. Salvanes } \\
\text { E. Ø. Sørensen }\end{array}$ & $\begin{array}{l}\text { The Impact of a Primary School Reform on } \\
\text { Educational Stratification: A Norwegian Study of } \\
\text { Neighbour and School Mate Correlations }\end{array}$ & 5 & $12 / 03$ \\
\hline 954 & $\begin{array}{l}\text { P. Portugal } \\
\text { J. T. Addison }\end{array}$ & Six Ways to Leave Unemployment & 6 & $12 / 03$ \\
\hline
\end{tabular}

An updated list of IZA Discussion Papers is available on the center's homepage www.iza.org. 